\title{
ATTITUDES TOWARDS SAME-SEX PARTNERSHIP: A SOCIOLOGICAL RESEARCH OF YOUNG PEOPLE IN SPLIT (CROATIA) Gorana Bandalović $^{1}$, Zorana Šuljug Vučica ${ }^{2}$, Ines Uvodić ${ }^{3}$
}

\begin{abstract}
One of the current dilemmas of modern society is how to look at homosexuals, same-sex partners, forming samesex partnerships, and raising children in such communities. Homosexuals are classified as sexual minorities and are often excluded from society, which is not new because members of sexual minorities have long been accompanied by numerous persecutions and repressions. This paper aims to examine the attitudes of young people towards homosexuality and same-sex partnership. The paper presents the results of the research conducted in 2019 using a survey method on a sample of 303 respondents aged 15 to 35 years. The results show that most young people do not consider homosexuality to be a disease and approach LGBT people in the same way as the rest of society, not paying attention to someone's sexual orientation. Respondents are predominantly open to the possibility of marriage between same-sex partners while they to a lesser extent agree with the adoption and upbringing of children by same-sex partners. They believe that there is a difference in the upbringing of children raised by same-sex partners from children raised by heterosexual partners, which can be justified by the discrimination and violence to which children of same-sex partners are exposed to. Also, young people think that homosexual parents can be good parents and provide their children with everything they need and that it is better for children to grow up in same-sex families than in homes for abandoned children. Although they state that such communities are almost equal to heterosexual communities, they are aware of their exposure to social exclusion.
\end{abstract}

UDC Classification: 316.36, DOI: https://doi.org/10.12955/pss.v2.199

Keywords: same-sex partnership, youth, children, sociological research.

\section{Introduction: The position of sexual minorities in the last 100 years in Croatia}

Members of sexual minorities have long been persecuted and repressed. To preserve their own lives, members of sexual minorities were forced into hiding (Itaborahy \& Zhu as cited in Vučković Juroš, 2015). Thus, homosexuals along with Jews and Roma were the victims of German concentration camps. After World War II, the position of homosexuals in the new Yugoslav communist regime was not much better. In Yugoslavia, sexual minorities were then persecuted in what led to numerous trials and prison sentences. Culminations could be observed in the 1950s when male homosexuality was criminalized (Mondimore as cited in Vučković Juroš, 2015). ${ }^{4}$ Despite the events going on in the world, progress in Croatia in terms of the position of sexual minorities became visible only in the 1980s. During that period their position in society began to be discussed more and new social movements such as peace, environmental and feminist movements were strengthened. Initiatives for the establishment of the first lesbian organization in Croatia appeared in 1989, which was a kind of turning point because homosexuality became visible in the media as well as in popular culture (Vuletić as cited in Vučković Juroš, 2015).

However, while in the 1990s some countries progressed and broadened their horizons regarding sexual minorities, this was not the case in Croatia. During the Homeland War in Croatia (1991-1995), all

\footnotetext{
${ }^{1}$ Associate Professor; University of Split (Croatia); Faculty of Humanities and Social Sciences; Department of Sociology; gbandalo@ffst.hr; ORCID 0000-0003-0136-3690

${ }^{2}$ Associate Professor; University of Split (Croatia); Faculty of Humanities and Social Sciences; Department of Sociology; zorana@ffst.hr; ORCID 0000-0003-4969-3859

${ }^{3}$ B.A. of Sociology and Master Student; University of Split (Croatia); Faculty of Humanities and Social Sciences; Department of Sociology; iuvodic@ffst.hr

${ }^{4}$ At the same time, some events were taking place in the United States that helped put LGBT activists on the map of political actors in the second half of the 20th century and made the public aware of the existence and problems of the homosexual population. Thus, in 1973, the American Psychiatric Association (APA) officially deleted "homosexuality" from the list of mental disorders because of the argument that homosexuality was a natural variation of sexual behavior, not a deformity (Mondimore as cited in Vučković Juroš, 2015). Gradually, the first American organizations for the rights of homosexuals developed, so they became visible in the media. The turning point was the so-called Stonewall riots in New York in 1969. This prompted the mobilization of homosexual activists seeking basic civil rights in the 1960s and 1970s (Vučković Juroš, 2015). In the United States, in the '80s the movement for civil rights of homosexuals entered a new phase, expanding the requirements from recognizing equality to seeking full inclusion in all social institutions, such as education, the labor market, health, military, etc. During the ' 90 s there were numerous campaigns for partnership recognition, same-sex marriage, and child adoption (D'Emilio as cited in Vučković Juroš, 2015).
} 
processes of progress in the form of acceptance of homosexuals, which began ten years earlier, were interrupted (Vučković Juroš, 2015). The political party Croatian Democratic Union came to power, which was closely connected with the Catholic Church, whose social, cultural, and political influence grew in the 1990s on a national and global level (Đurin, 2018). Such a population of people was considered a real threat to the state that was trying to rebuild. In the 1990s, there were no public debates on homosexuality and sexual minorities, their works did not receive any official support, and members often hid because of discrimination and violence, and homophobia gradually developed (Vuletić as cited in Vučković Juroš, 2015). Changes occurred in 2000 when the left-wing coalition led by the Social Democratic Party (SDP) took over, providing more support for sexual minorities. The first Pride Parade was held in Zagreb in 2002, and the first Queer Zagreb Festival in 2003. At the beginning of the 21st century, some changes in Croatian legislation and public discourse happened. It was believed that sexual minorities must no longer be ignored and that discrimination and the right of LGBT people were something that Croatian society should deal with (Vučković Juroš, 2015).

Along with the changes that took place, certain changes regarding the laws also occurred. Thus, for example, the Law on Same-Sex Communities was passed in 2003, although it did not enter into force. The problem was that it was not possible to register a partnership, which meant that the rights of sexual minorities could only be realized after the break-up of the relationship, and only if same-sex partners could have proven three years of living together (Juras as cited in Vučković Juroš, 2015). As cited in the articles of the Law on Same-Sex Communities, the effects of same-sex unions are as follows: such persons have the right to support one of the partners, the right to acquire and regulate mutual relations regarding property and mutual assistance (Klasiček, 2013). In the Republic of Croatia, same-sex partners do not enter "the circle of legal heirs", and mutual inheritance is possible only if the other partner is appointed as the heir in a valid will. Although individual same-sex partners meet all the necessary conditions for their relationship to be considered a same-sex union and the fact that it is compared to a marital/extramarital union, such persons will not be able to be each other's legal heirs. Children are always the legal heirs of their parents. But, in the case of same-sex partners, this is not possible. Such families face the problem of inheritance because the child cannot inherit a partner who is not his biological parent or adoptive parent (Klasiček, 2013).

The Same-Sex Life Partnership Act in the Republic of Croatia was adopted in 2014. Until the adoption of this Law, the position of same-sex communities in Croatia was regulated by a legal framework that proved ineffective. It is prescribed that the principle of social equality of all citizens individually, as well as of the social groups to which they belong (minority or majority) is a fundamental value of the Croatian constitutional order (The Ministry of Administration, 2014). Since it has been possible to enter into a same-sex marriage, the definition of marriage as a community of life of persons of different sexes has changed. However, same-sex partners still have partially limited legal influence. Namely, changes in legal norms in the field of family law are not in line with changes in other areas of law such as inheritance, social, and tax rights. Thus, for example, the differences between same-sex and traditional marriage in the Family Act are most visible regarding parental rights and the right to adoption (Krešić, 2015). As cited in Krešić (2015), the process of legalization of registered partnerships in the countries of the European Union is dynamic. The process of recognizing same-sex communities is constantly present, and the rights of same-sex partners are expanding. Although the process of legalization of a registered partnership is not the same in all European Union countries but is seen to be progressing (Krešić, 2015). The process of legalization of same-sex communities must be accompanied by certain factors such as cultural and social conditions in all states. This includes the rate of heterosexual extramarital communities, the degree of religiosity of the population, and tolerance towards people of homosexual orientation. These three factors usually influence the model of same-sex life that will be accepted in a state (Badgett as cited in Krešić, 2015).

Members of homosexual communities are still largely socially excluded. ${ }^{5}$ Thus, for example, the exclusion of members of sexual minorities from the democratic legal system points that they are still

\footnotetext{
${ }^{5}$ The term social exclusion is vague, unclear, and ambiguous. It can mean the failed integration of one or more systems such as the democratic-legal system, the labour-market, the social welfare system, and family and local community systems. Exclusion is a structural characteristic that is the result of the relationship between power and inequality in society (Šućur, 2004).
} 
unequal to other citizens regarding the democratic legal order, which on the other hand implies a violation of human, civil and political rights. The problem is that the identity of an LGBT person is not considered as valuable as other identities (Šućur, 2004). The first step towards achieving civil equality of sexual minorities was achieved in the Socialist Federal Republic of Croatia in 1977 when homosexual relations were decriminalized (ILGA-Europe as cited in Vučković Juroš, 2015). Furthermore, exclusion from the labour market system implies impossible or difficult economic integration, which means impossible or difficult access to employment and economic goods (Šućur, 2004). Thus, for example, hiding one's sexual orientation is not an acceptable solution in a democratic and free society. This usually refers to discrimination in employment, especially regarding certain types of jobs, and discrimination at the workplace. In other words, it is often the case that members of sexual minorities hide their sexual orientation at the workplace (Takacs as cited in Vučković Juroš, 2015). Exclusion from the family and local community systems is also noticeable. It implies difficult interpersonal integrations such as maintaining ties and relationships with family members, friends, and neighbours (Šućur, 2004). LGBT individuals even in their own family face misunderstanding and exclusion especially if it is a traditional family. Emotional and physical violence usually appears in such families (Vučković Juroš, 2015). Sexual minorities are usually excluded from the local community as well. For this reason, this group is often compared to one of the most stigmatized groups, the Roma people (Dekić as cited in Vučković Juroš, 2015).

\section{Same-sex communities and parenting}

In the social sciences, the term "family of choice" is used as a name for all alternative ways of family life that differ from the modern heterosexual nuclear family model. Heterosexuality is no longer the only basis of parenthood. This form of family leads to the establishment of new relationships between biological and/or social parents, friends, and acquaintances who in the past belonged exclusively to the heterosexual nuclear family (Švab, 2007). Non-recognition of same-sex partnerships and ignoring their rights can be compared and equated with discrimination based on gender, race, age, nationality, religion, disability, etc. The most common victims of discrimination, violence, humiliation, and ridicule are children who are members of LGBT families. Not recognizing the LGBT family damages their rights (Mršević, 2008).

Late modern trends in the pluralization of family life include various ways of organizing family life and parenthood, which includes the so-called "gayby boom". In Western countries, more and more homosexual couples and single homosexuals/lesbians are opting for parenthood and family life. Lesbian families often reshape the role of the father. Within a lesbian family, involving the father as an active parent in daily life leads to the expansion of this type of family. Those lesbians who have children from previous heterosexual relationships, form and define new parental relationships in the context of the process of family reorganization and relationships. A more radical reshaping of the concepts of fatherhood and the identification of parental relationships takes place in lesbian couple partnerships who decide to have a child by using the sperm of a known or unknown donor. In doing so, they make a decision not only about a sperm donor's unknown identity but also about his sexual orientation. SwedishIrish researchers showed that lesbians often opt for gay donors. One reason for this decision is the shared history of oppression through homophobic discrimination as well as the belief that gay fathers are more committed to children and more reliable than heterosexual ones. Gay fathers are considered a better example of masculinity for children because they provoke hegemonic depictions of masculinity which is perceived as an advantage ( ̌̌vab, 2007).

Many studies have shown that there is no difference in the upbringing of children raised by same-sex partners from children raised by heterosexual partners. The data suggest that single parents, as well as same-sex partners who adopt a child, can raise children just as well as heterosexual families. The sexual orientation of the parents is not crucial, nor does it affect the development of the child. The environment in which a child grows up is important, as well as love and care. Regardless of the sexual orientation of the parents, children growing up in a good/adequate environment have acceptable behaviour (Mršević, 2008). Lesbians and homosexuals, in any sense, are capable and fit to be parents full of love, understanding, and attention like heterosexual parents. The most important thing for children is to grow up happy, healthy, adjusted, and stress-free. Research confirms that it is very important for children to grow up in a family atmosphere with minimal quarrels, maximum support, and good relations between children and parents. What children certainly do not need is discrimination. All children should have 
equal social opportunities to achieve their maximum development. Therefore, children of homosexual partners must have all benefits that other children have, such as health care, education, the standard of living, etc. (Mršević, 2009). Accordingly, Vučković Juroš points out that scientists should focus on discussing the specific problems that result from inequality and stigmatization that affect families of same-sex couples and LGBT individuals and affect the outcomes of their children. Such a discussion should also raise awareness of how equalizing the social context for all forms of a family can contribute to a child achieving better outcomes (Vučković Juroš, 2017).

Mršević points out that children who grow up with same-sex parents face a "difficulty phase". It is difficult for them to understand why their family is different from the families of other children. However, it is part of growing up, but also an experience that will help them later in life. As in any family, in the family of same-sex partners, quarrels should be reduced to a minimum, and the support and close relationship between the child and the parents should be maximized. Research confirms that children raised by lesbian couples are healthy and well-adjusted. Psychological tests show no differences regarding other children (Mršević, 2008). However, children raised by same-sex partners are often the subject of ridicule by other children. Despite numerous prejudices that same-sex marriage will lead to the spread of prostitution, polygamy, and incest, it has been shown that there are no rational reasons to confirm this. Czech researchers have shown that children should grow up in same-sex families rather than in homes for abandoned children. Hawaiian researchers have confirmed that there is no significant difference if children who are raised by parents of the same sex. Same-sex partners have every predisposition to raise happy, healthy, satisfied, and adjusted children (Mršević, 2008).

\section{Methodology}

\section{Research objectives}

The basic goal of the research was to examine the attitudes of young people towards homosexuality and same-sex partnerships.

The specific goals of the research were to:

- examine whether there was a difference in the attitudes of men and women towards gay people and lesbians,

- determine whether there was a difference in attitudes towards persons of homosexual orientation depending on political orientation,

- examine whether there was a difference in attitudes towards persons of homosexual orientation depending on the degree of (non)religiosity and attitudes towards the Catholic Church.

\section{Research hypothesis}

Following the set goals, the following research hypotheses are set:

H1: Men have a more negative attitude towards LGBT people and same-sex partnerships than women.

H2: People who are politically "more right-wing" find it harder to accept same-sex partnerships than those who are "more left-wing".

H3: More religious people find it harder to accept same-sex partnerships than non-religious ones.

\section{Method and sample}

The survey was conducted in 2019 by using a survey on a convenient sample of 303 respondents aged 15 to 35 years, with 176 women $(58.1 \%)$ and 127 men (41.9\%) surveyed. The most represented group of respondents are those aged 20 to $24(67 \%)$. The largest number of respondents live in the city $(90.4 \%)$, then in the countryside (5.6\%), while the least on an island (4\%). Most of the respondents have completed an undergraduate level of education (39.9\%), 39.3\% finished high school and 15.2\% completed graduate studies. More than half of the respondents are religious $(52.1 \%)$, apolitical $(56.8 \%)$, while $15.2 \%$ of respondents belong to the "left", $14.2 \%$ to the "centre" and $13.9 \%$ of young people are right-wing.

\section{Results}

The results of the survey show that the majority of respondents $(80.5 \%)$ think that they should not pay attention to the sexual orientation of LGBT people and that LGBT people should be approached in the same way as the rest of society in comparison to $1.7 \%$ of those who think that LGBT people should be stigmatized and separated from the rest of society. At the same time, $65.3 \%$ of young people do not 
consider homosexuality a disease, instead they think that we can speak of it as something with which an individual was born with. But there are still $8.3 \%$ of those who view homosexuality as a disease that occurs over the years. More than half $(57.1 \%)$ of respondents disagree with the statement that it is necessary to know the sexual orientation of the interlocutor in a conversation, so $69 \%$ of respondents point out that they behave equally in a conversation with both a homosexual and heterosexual person. Regarding the maturity of society and the acceptance of different sexual orientations, almost half $(46.9 \%)$ of respondents state that society today is partially ready for this. Nevertheless, more than half $(52.1 \%)$ of the respondents think that the Church has a significant influence on the development of homophobia in society.

Furthermore, the attitudes of young people about the social exclusion of homosexuals were examined. Slightly less than half (48.2\%) of respondents think that the identity of an LGBT person is not as valuable as other identities, and they state that the human rights of the members of sexual minorities are violated (43.9\%). Accordingly, we were interested in the opinions of young people regarding the employment of LGBT people. The data show that $28.7 \%$ of respondents still think that LGBT people find it harder to find employment, and $48.2 \%$ of respondents think that sexual minorities hide their sexual orientation at the workplace. This data is in line with previous research (Vučković Juroš, 2015) which indicated the presence of discrimination regarding the employment of LGBT people and discrimination at the workplace, where such individuals encountered numerous negative comments from colleagues. So, it is not unusual that members of sexual minorities hide their sexual orientation at the workplace. Although more than a third (39.3\%) of respondents think that children are taught to respect diversity in educational institutions, a large number of respondents (70.6\%) state that there is psychological and physical harassment of LGBT people during education. Accordingly, young people agree that LGBT people find it more difficult to maintain relationships with family members, friends, and neighbours (41.3\%) and conclude that sexual minorities are excluded from the local community (37\%).

At the same time, the attitudes of young people about the possibility of same-sex marriage were examined. The results suggest fairly liberal responses. Namely, $65.3 \%$ of respondents think that it is acceptable for same-sex partners to enter into a community such as a marriage, and $50.8 \%$ of respondents agree with the statement that non-recognition of same-sex unions and ignoring their rights is equal to discrimination based on sex, race, nationality, religion, and disability. Therefore, for half $(51.5 \%)$ of respondents, homosexual partners should have the same rights and obligations as heterosexual partners. Here, we were interested in whether there were differences in the attitudes of young people towards marriage between persons of the same sex concerning their gender, politics and religiosity of the respondents. To test these hypotheses, chi-square tests were performed. The results show that there is a statistically significant difference in attitudes regarding gender $(\chi 2=7.560 ; \mathrm{df}=2 ; \mathrm{p}=0.023)$, with a significantly higher number of women $(61.1 \%)$ than men $(38.9 \%)$ supporting same-sex marriage. It follows that the $\mathrm{H} 1$ hypothesis is accepted, which assume that men have more negative attitudes towards LGBT people and same-sex partnerships than women. A statistically significant difference is also shown regarding politics $(\chi 2=49.444 ; \mathrm{df}=6 ; \mathrm{p}=0.000)$. The results show that the least number of respondents who support same-sex marriage are right-wing (6.6\%), while those who more support same-sex marriage are left-wing (21.7\%). Therefore, the $\mathrm{H} 2$ hypothesis is also accepted, which assumes that people who are politically "more right-wing" have more difficulty accepting same-sex partnerships than those who are "more left-wing". The analysis also shows that there is a statistically significant difference regarding the religiosity of the respondents $(\chi 2=45.773 ; \mathrm{df}=4 ; \mathrm{p}=0.000)$, with $38.4 \%$ of religious respondents accepting same-sex marriage, while $47 \%$ of non-religious respondents are inclined to do so. Thus, the $\mathrm{H} 3$ hypothesis is also accepted. It assumes that more religious people find it harder to accept same-sex partnerships than non-religious ones. The data also show that more than half $(56.4 \%)$ of respondents think that more religious countries such as Poland, Croatia, and Italy find it harder to accept same-sex communities, while more developed countries such as Finland and Germany are more open to same-sex marriage (55.2\% of respondents). This data is in line with earlier statements (Mršević, 2009) which point out that in 1998 the Vatican condemned same-sex partnership laws that were in force in some European countries. Namely, the International Lesbian and Gay Association (ILGA) accused the top of the Catholic Church of persecuting homosexuals for 2000 years, which was not the case with the Protestant Church. The Catholic Church did not support homosexuals during the Nazi persecution as well as it did not protest against the mass killings of homosexuals in Catholic countries such as 
Mexico and Brazil. In this sense, the only thing the Vatican has spoken about, regarding homosexual partners, refers to the statement condemning the law on registered partnership, which has been understood as reversing and neglecting the human rights of same-sex persons (Mršević, 2009).

Furthermore, almost half (49.2\%) of respondents approve of the adoption of children in a same-sex community in comparison to a higher percentage of those who approve of the marriage. In other words, a third $(33.3 \%)$ of the surveyed people are not inclined to do so. This data is in line with previous research (Mršević, 2008) as cited in which openness to same-sex marriage does not imply support for the adoption of children by same-sex partners. The Netherlands has the primacy regarding the adoption of children in same-sex communities. However, it is interesting that some countries such as Germany and Spain provide more support for child adoption in comparison to same-sex marriage, while Denmark, which ranks first in support of same-sex marriage, is only in fourth place regarding the support for child adoption (Mršević, 2008).

Accordingly, 59.7\% of respondents think that same-sex partners can raise a child/children adequately, while $21.1 \%$ of the surveyed population disagree. But when asked about the difference in the upbringing of children raised by same-sex partners and children raised by heterosexual partners, quite interesting results are obtained. Half (49.5\%) of respondents think that the difference in the growth of children still exists and there are $25.4 \%$ of those who think that there is no difference, as well as $25.1 \%$ of those who do not know. At the same time, respondents think that homosexual parents can form a healthy family atmosphere in which they will raise healthy and well-adjusted children (54.8\%), so children of samesex partners should be completely equal to children of heterosexual parents $(82.8 \%)$. Nevertheless, $40.3 \%$ of respondents state that children raised by same-sex partners are often victims of discrimination and violence from other children. Also, the majority (64\%) of respondents think that children should grow up in same-sex families rather than in homes for abandoned children. Respondents are also interested in the fact that same-sex partnerships can be an important demographic potential for starting a family and raising children in those European countries where the birth rate is very low, with which $35 \%$ of respondents agree. Finally, we investigated whether young people thought that artificial insemination of lesbians should have been viewed in the same way as artificial insemination of heterosexual women. As cited in the data, slightly more than half $(54.1 \%)$ of respondents think that artificial insemination of lesbian and heterosexual women should be equal, but still, $19.5 \%$ of respondents disagree.

\section{Conclusion}

"Families of choice" play an important role in the transformation of the modern family institution based on heterosexual parenting, but often same-sex communities are not well accepted in society. Since nonrecognition of the existence of same-sex partnerships and ignoring their rights can be seen as a type of discrimination, the question arises as to how "open" are society and youth in the Republic of Croatia towards same-sex marriage?

The results of the research show that, compared to the past, most respondents think and treat LGBT people positively and do not consider homosexuality a disease, which indicates the absolute progress of society, but, in their opinion, LGBT people are still in the Republic Croatia (and in Split) extremely vulnerable to social exclusion and are exposed to mental and physical harassment during schooling, as well as discrimination in employment and at the workplace. The majority of respondents support samesex marriage, while support for the adoption of children in the same-sex community is not so high as support for marriage. It can also be noted that more than half of the respondents think that same-sex partners can raise a child/children in a healthy family environment, but that there is a difference in the growth of children living with same-sex partners compared to children living with heterosexual partners. The difference is often attributed to the discrimination and violence to which such children are exposed. So, most respondents stress that children of same-sex partners should be equal to children of heterosexual parents.

The data also show that men have more negative attitudes than women towards LGBT people and samesex partnerships, that people who are "more right-wing" are more politically oriented than those who are "more left-wing" and that more religious individuals find it harder to accept same-sex relationships than non-religious. Therefore, all three set research hypotheses are accepted. Finally, it can be concluded that young people today are quite open to forming same-sex partnerships, entering same-sex marriage, 
and raising children in such families. Despite the progress of society in terms of thinking about LGBT individuals, it is necessary to constantly encourage and develop the awareness of young people about equality and the rights of all members of society.

\section{References}

Đurin, S. (2018). Queer aktivizam i transformacija grada: kako se LGBTIQ zajednica bori za svoje prostore u gradu Zagrebu [Queer activism and the transformation of the city: How the LGBTIQ community is fighting for its space in the city of Zagreb]. Narodna umjetnost: hrvatski časopis za etnologiju $i$ folkloristiku, 55(2), 75-103. Retrieved from https://doi.org/10.15176/vol55no204

Klasiček, D. (2013). Zakonsko nasljeđivanje istospolnih partnera u Republici Hrvatskoj u postojećem zakonskom okviru [Intestate inheritance of same-sex partners in the Republic of Croatia within the existing legal framework]. Zbornik Pravnog fakulteta sveučilišta u Rijeci, 34(2), 963-989. Retrieved from https://bit.ly/213w6IK

Krešić, B. (2015). Zajednice života osoba istog spola u pravu zemalja Evropske unije [Community life of same sex people in the law of the countries members of the European Union]. Sarajevo: Sarajevski otvoreni centar. Retrieved from https://bit.ly/2OwOWti

Mršević, Z. (2008). Istopolne zajednice i deca [Same sex families and children]. Stanovništvo, 1(2009), 23-47. Retrieved from https://bit.ly/2I8vUbw

Mršević, Z. (2009). Ka demokratskom društvu - istospolne porodice [Towards a democratic society: same-sex families]. Beograd: Institut društvenih nauka.

The Ministry of Administration (2014). Zakon o životnom partnerstvu [Same-sex Life Partnership Act]. Retrieved from https://bit.ly/2uDRmgp

Šućur, Z. (2004). Socijalna isključenost: pojam, pristupi i operacionalizacija [Social exclusion: definitions, discourses and operationalization]. Revija za sociologiju, 35(1-2), 45-60. Retrieved from https://bit.ly/2FLQETp

Švab, A. (2007). New Ways of Parenting: Fatherhood and Parenthood in Lesbian Families. Revija za sociologiju, 38(1-2), 4355. Retrieved from https://bit.ly/2UWX0FP

Vučković Juroš, T. (2015). Socijalna isključenost seksualnih manjina u Hrvatskoj [Social exclusion of sexual minorities in Croatia]. Revija za socijalnu politiku, 22(2), 195-217. Retrieved from https://bit.ly/2WINruN

Vučković Juroš, T. (2017). Usporedba ishoda djece iz obitelji istospolnih i raznospolnih partnera: osvrt na kvantitativne studije provedene na slučajnim reprezentativnim uzorcima [Comparing the outcomes of children of same-sex and opposite-sex partners. Revija za sociologiju, 47(1), 65-95. Retrieved from https://bit.ly/2WFhWlg 